\title{
Private Sector Corruption, Public Sector Corruption and the Organizational Structure of Foreign Subsidiaries
}

\author{
Michael A. Sartor ${ }^{1}$ Paul W. Beamish ${ }^{2}$
}

Received: 28 May 2018 / Accepted: 13 March 2019 / Published online: 4 April 2019

(c) The Author(s) 2019

\begin{abstract}
Corporate anti-corruption initiatives can make a substantial contribution towards curtailing corruption and advancing efforts to achieve the United Nations' Sustainable Development Goals. However, researchers have observed that underdeveloped assumptions with respect to the conceptualization of corruption and how firms respond to corruption risk impeding the efficacy of anti-corruption programs. We investigate the relationship between the perceived level of corruption in foreign host countries and the organizational structure of subsidiary operations established by multinational corporations (MNCs). Foreign host market corruption is disaggregated into two components-private and public corruption. We employ an uncertaintybased perspective grounded in transaction cost theory to focus upon the distinct mechanisms through which private and public corruption can each be expected to impact a foreign subsidiary's organizational structure [wholly-owned subsidiary (WOS) or a joint venture (JV) with a local partner]. We expect that each type of corruption fosters a different type of uncertainty (environmental or behavioral) which predominates in shaping the MNC's choice of foreign subsidiary investment structure. Hypotheses are developed and tested with a sample of 187 entries into 19 foreign host markets. Each type of corruption was found to exert a distinct effect upon the organizational structure of foreign subsidiaries. More precisely, while heightened perceived levels of public corruption were found to motivate MNCs to invest through a JV with a local partner rather than a WOS, more pronounced private corruption precipitated the opposite outcome.
\end{abstract}

Keywords Corruption $\cdot$ Uncertainty $\cdot$ Multinational corporations $\cdot$ Foreign subsidiaries · Organizational structure

\section{Introduction}

Corruption is a relentless grand global challenge that has been implicated as the root cause of numerous social and economic maladies (Argandoña 2007). The Sustainable Development Goals (SDG) agenda developed by the United Nations (UN) is comprised of 17 goals that have been designed to protect the planet and improve the living conditions of its inhabitants (Voegtlin and Scherer 2017). One of these goals (SDG 16) targets to "substantially reduce corruption and bribery in all their forms" (United Nations

Michael A. Sartor

michael.sartor@queensu.ca

Paul W. Beamish

pbeamish@ivey.ca

1 Smith School of Business, Queen's University, 143 Union Street W., Kingston K7L 3N6, Canada

2 Ivey Business School, Western University, 1255 Western Road, London N6G 0N1, Canada
2015). The gravity of this imperative is undeniable given the recent sobering observation that more than $80 \%$ of the world's population lives in a country with "a serious corruption problem" (Transparency International 2016). Scholars have concluded that corruption has become one of the world's most pressing challenges, affecting "environmental protection efforts, human rights, national security, access to healthcare and justice services, economic development and the legitimacy of governments around the world" (Feathers 2014, p. 287). In fact, researchers and policy makers have observed that corruption is particularly harmful to humans and society because it threatens to undermine progress with respect to several other pressing SDGs that have been developed to reduce inequality and improve living standards (Trapnell et al. 2017). As examples, the SDGs adopted by the UN include goals pertaining to the alleviation of poverty (SDG 1), enhancing health and well-being (SDG 3), improving education (SDG 4), and ensuring access to clean water and sanitation (SDG 6). However, scholars have found that corruption adversely impacts health and well-being by 
limiting access to public health clinics, reducing immunization rates and delaying the vaccination of newborns (Azfar and Gurgur 2008). Further, countries characterized by widespread corruption have experienced lower levels of educational attainment and a lower likelihood that their citizens will escape the poverty trap (Eicher et al. 2009). Researchers have also found a statistically significant negative relationship between the level of corruption in a country and access to both adequate drinking water and sanitation (Anbarci et al. 2009). Consequently, reducing corruption has become an important component of the sustainable development agenda (Trapnell et al. 2017).

In elaborating a role for management researchers in efforts to address the grand challenges highlighted by the UN's SDGs, George et al. (2016) propose that scholars should focus on deepening our comprehension of stubborn societal problems. Building on this proposition, researchers have observed that corporate anti-corruption programs can play a central role in both combatting corruption (Argandoña 2017a) and attaining sustainable development because "anti-corruption efforts...underpin the achievement...of all other SDGs" (Trapnell et al. 2017, p. 36). However, assessments with respect to the efficacy of corporate anti-corruption codes and programs have been mixed. While some have suggested that they have shown some "ability to foster ethical behaviors" (Mercier and Deslandes 2017, p. 781), others have concluded that there is "no definitive evidence that codes have a significant effect on ethical behavior in organizations" (Painter-Morland 2010, p. 266). Heeks and Mathisen (2012) propose that the effectiveness of anticorruption initiatives can be undermined by "design-reality gaps" whereby theoretical assumptions embedded within the design of anti-corruption programs fail to accurately reflect the reality of the contexts within which these initiatives are deployed. Two prominent sources of potential misalignment include a narrow conceptualization of corruption (Persson et al. 2013) and an underdeveloped comprehension of how firms respond to corruption (Hansen 2011). Consistent with this perspective, scholars have observed that two assumptions frequently underpin the strategic and policy prescriptions of anti-corruption theorists. First, corruption is conceptualized as occurring primarily within a multinational corporation's (MNC's) public sector transactions with government officials and bureaucrats (Goel et al. 2015). In this regard, legal scholars (Green 2013) and economists (Hodgson and Jiang 2007, p. 1043-1044) have observed that the prevailing conceptualization of corruption has constrained the scope of research inquiry "to the public sector, despite the fact that private sector corruption is often acknowledged." Second, engaging a "middleperson" such as a joint venture $(\mathrm{JV})$ partner is assumed to be a key strategy employed by MNCs to manage the uncertainty and transaction costs precipitated by more pronounced government corruption (Bray 2005; Drugov et al. 2014). Consequently, the efficacy of scholarly recommendations with respect to corporate anti-corruption programs risks being impeded by underdeveloped assumptions with respect to how corruption is conceptualized and how firms respond to corruption.

To address these limitations, business ethics scholars have become more focused upon enhancing our understanding of the various types of corruption that firms encounter in foreign markets (Luiz and Stewart 2014; Van Vu et al. 2018), as well as the different strategic, structural and operational responses of MNCs to heightened levels of corruption (Godinez and Liu 2018; Orudzheva et al. 2018; Xie et al. 2018). In doing so, ethics scholarship (Clark and Brown 2015; Gago-Rodríguez et al. 2018; Hauser 2018; Remišová et al. 2018) is generating new research insights that are helping to inform the efforts of anti-corruption scholars who endeavor to design better strategies to curb MNC engagement in foreign market corruption.

We build on this research tradition in the ethics literature in two important ways. First, we leverage the work of business ethicists' who have advocated in favour of broadening the conceptualization of corruption and elaborating the nature and effects of different types of corruption, particularly private sector corruption and public sector corruption (Argandoña 2003, 2017b; Gopinath 2008). Second, we extend the work of ethics scholars who have theorized that corruption and the uncertainty that it precipitates may impact the organizational structure of foreign subsidiary investments (Godinez and Liu 2018; Luiz and Stewart 2014). In this regard, Montiel et al. (2012) have proposed that different manifestations of corruption may precipitate distinct uncertainties for firms and exert disparate impacts upon firm decision-making.

As such, we ask: How do the perceived levels of public sector (government) corruption and private sector (non-government) corruption impact upon the organizational structure of a MNC's foreign subsidiaries? We apply an uncertainty-based perspective (Sartor and Beamish 2018) to focus on the distinct mechanisms through which the two types of corruption can be expected to influence the structure of foreign subsidiary investments. When MNCs enter into foreign markets characterized by more pronounced host market corruption, we anticipate that public and private corruption will each exert distinct effects upon the organizational structure of their subsidiaries. This is because each type of corruption can be expected to foster different types of uncertainty and risk which predominate in shaping the MNC's choice with respect to the structure of its foreign subsidiary (wholly-owned subsidiary (WOS) versus JV with a local partner). In the case of public corruption, we expect that environmental uncertainty and knowledge-based risk will be the primary uncertainty and risk influencing the MNC's structural decision. Conversely, in the case of private 
corruption, behavioral uncertainty and opportunism-based risk will predominate in shaping the MNC's preference.

Hypotheses are developed pertaining to the impact of each type of corruption upon a MNC's choice between a WOS and a JV with a local partner. We test these hypotheses and find that each type of corruption exerts a distinct impact upon the organizational structure of foreign subsidiary investments. More precisely, while heightened levels of public corruption were found to motivate MNCs to invest through a JV with a local partner rather than a WOS, more pronounced private corruption precipitated the opposite outcome.

Our research makes several contributions. First, building on ethics scholarship that has expanded the conceptualization of corruption, we apply an uncertainty-based perspective to examine the effects of both private and public corruption upon the strategic decisions of foreign-investing MNCs. Second, our findings bolster the efforts of theorists who have endeavored to enhance our understanding of the impact of corruption upon the organizational structure of foreign subsidiaries. Third, we contribute new insights which serve to broaden the set of assumptions that can be employed by scholars who develop prescriptions that are intended to narrow design-reality gaps in corporate anti-corruption programs. In doing so, our work responds to George et al. (2016, p. 1887) who urge management researchers to assist in the transformation of "stubborn societal problems into tractable managerial challenges" for which solutions can be devised. In this regard, our research buttresses the efforts of business ethics scholars, policy makers and managers who strive to both curtail MNC engagement in overseas corruption and advance the UN's sustainable development agenda.

The remainder of our paper is organized as follows. In the "Theory and Hypotheses" section, we present some of the literature that has contributed to elaborating the distinction between private and public corruption, in addition to highlighting some of the main tenets of transaction cost theory. Moreover, we review the uncertainty-based perspective that we apply in our work and we present hypotheses with respect to the impact of both private and public corruption upon the organizational structure of foreign subsidiaries. We describe our study's sample and discuss both the estimation techniques and variable measures in the "Methods" section, followed by the presentation of our empirical findings in the "Results" section. In the "Discussion and Conclusions" section, we summarize our study, highlight its contributions and discuss its potential limitations.

\section{Theory and Hypotheses}

\section{Public Sector Corruption and Private Sector Corruption}

To describe the nature of corrupt activities, business ethics scholars have referred to various taxonomies such as market versus parochial corruption (Husted 1994), bureaucratic versus political corruption (Lindgreen 2004), petty versus grand corruption (Argandoña 2005) and low-level versus systemic corruption (dela Rama 2012). Notably, these taxonomies have collectively focused on one type of corruption-government corruption. Consequently, researchers have routinely defined corruption as the abuse of public power for personal gain. While succinct, the narrow conceptualization of the construct has limited study to the domain of bureaucratic activity and restrained what scholars choose to study, model and report (Hodgson and Jiang 2007). Notwithstanding the important insights that have been generated by prior research that has focused on government corruption, business ethicists have continued to advocate in favor of broadening corruption-based research to incorporate a consideration of both public corruption and private corruption (Argandoña 2003, 2017b; Gopinath 2008). As such, other taxonomies such as policyspecific versus widespread or general corruption (Montiel et al. 2012), and procedural versus schematic versus categorical corruption (Aguilera and Vadera 2008) have emerged and challenged scholars to start incorporating a consideration of private sector corruption in their work. In distinguishing private sector corruption from public sector corruption, ethics theorists maintain that private sector corruption involves the abuse of power within private sector (non-governmental) organizations (Argandoña 2003).

Gutmann and Lucas (2018) have extended this conceptualization by highlighting four segments of the private sector within which private sector corruption transpires, including businesses, non-governmental organizations (NGOs), religious bodies and the media. Common examples of private sector corruption within business organizations include, among others, commercial bribery, kickbacks, corporate fraud, collusion and insider trading (Green 2013; Kim 2014; Zinnbauer et al. 2009). As other examples, Montiel et al. (2012) observe that some private firms may circumvent the substantial cost associated with implementing various ISO standards which operate as market-based mechanisms designed to signal a firm's commitment to procedures, policies and practices that contribute to sustainable growth (Aravind and Christmann 2011; Christmann and Taylor 2001). To do so, these private firms may endeavor to obtain certification in some international jurisdictions by paying bribes 
to private third-party auditors and certifiers which enable the firms to engage in symbolic rather than substantive implementation of standards such as ISO 9000 and ISO 14001 (Christmann and Taylor 2006). Researchers whose work has focused on combatting corruption within NGOs have observed that prevalent forms of abuse of power (or, corruption) within this type of private sector organization include the establishment of "fictitious NGOs" solely for the purpose of generating income for the organization's executives or Board members, the receipt of kickback payments by NGO employees from prospective vendors with respect to the procurement of goods or services for the organization, and the solicitation of bribes by NGO employees from prospective beneficiaries who seek inclusion on NGO aid distribution lists (The Economist 2017; Trivunovic et al. 2011). Corruption within religious organizations is manifest in the self-interested behavior of a religious organization's leaders and administrators who extract rents through embezzlement or wasteful spending of the organization's resources (Gutmann 2015). Finally, corruption in the media occurs when journalists, editors and other media employees solicit or accept bribes in exchange for publishing positive news that is known to be untrue (Spence 2017) or for suppressing the publication of negative or damaging news ( $\mathrm{Li} 2013$ ).

To provide a preliminary illustration of the distinction between public and private corruption, we refer to the recent experience of a MNC that was accused of engaging in both types of corruption through its subsidiaries in three foreign markets. The corporation (a provider of automated teller machines (ATMs) used by banks) was alleged to have engaged in public corruption with Indonesian and Chinese public officials who were empowered to influence the ATM-related contract decisions of government-owned banks in those two countries. At the same time, the MNC was also alleged to have engaged in private corruption with employees with similar decision-making powers in privately owned Russian banks (Gorman 2013; Jordan 2016). As another example, a MNC that manufactures tires settled charges pertaining to the alleged payment of bribes by its subsidiaries in Angola and Kenya to the employees of both government-owned entities (i.e., public corruption) and private companies (i.e., private corruption) in exchange for tire sales (Handa 2016; Holtmeier 2015).

\section{Transaction Cost Theory}

Business ethics scholars have employed the transaction cost lens to develop theory with respect to the impact of ethics-oriented concerns upon the organizational structure (Luiz and Stewart 2014; Robertson et al. 2010) and strategies of MNCs (Godinez and Liu 2018; Johnsen 2009; Xie et al. 2018). The tenets of transaction cost theory specify distinct types of uncertainty and costs. Environmental uncertainty includes any ambiguity in the operating environment (Karjalainen and Moxham 2013; Montiel et al. 2016) with respect to host government policies, procedures and practices which creates unpredictability for managers (Miller 1992). Information uncertainty is a type of environmental uncertainty that arises when managers' limited ability to collect and process information about the external environment (Grewatsch and Kleindienst 2017) makes it difficult for them to predict the outcomes of their decisions (Shi et al. 2015). When environmental uncertainty is more pronounced, firms experience greater knowledge-based risk which may impede their ongoing ability to navigate within foreign host market environments (Milliken 1987). Consequently, this need for new knowledge about the external environment precipitates greater information costs (North 1990) which are the costs associated with searching for information that is required to execute transactions in the host market (Madhok 1996). Collectively, environmental uncertainty and knowledge-based risk generally motivate a preference for hybrids over hierarchies (Geyskens et al. 2006), as firms endeavor to leverage a partner's knowledge and minimize their information costs.

Behavioral uncertainty is the uncertainty associated with predicting how others will behave (Krishnan et al. 2006). More pronounced behavioral uncertainty increases the risk of opportunism (Brouthers and Brouthers 2003). Opportunism is "behavior that takes advantage of a chance to deceive or mislead another party" (Smith 2018, p. 612). Partner opportunism is a persistent concern when firms engage in JV relationships (Li 2008). Consequently, an increased risk of opportunism stimulates more pronounced transaction costs, particularly monitoring and enforcement costs (Nooteboom et al. 1997; Romar 2004). While monitoring costs are the costs associated with ensuring that a party fulfills its predetermined obligations (Sampath et al. 2018), enforcement costs include the costs associated with sanctions or exerting control over a party that fails to fulfill its obligations (De Colle et al. 2014). Collectively, behavioral uncertainty and the risk of opportunism motivate firms to prefer vertical integration as they seek to minimize monitoring and enforcement costs (Geyskens et al. 2006).

Business ethics scholarship has conceptualized corruption as an institution that fosters uncertainty for foreigninvesting MNCs (Luiz and Stewart 2014). Milliken (1990, p. 58) observed that managers "experience several different types of uncertainty as they attempt to adapt an organization to its environment" and, as such, "aggregating uncertainty... may mask significant differences between types of uncertainty." As such, scholars have advocated in favor of elaborating the principle uncertainties that are precipitated by different institutions in more precarious foreign markets (Ahsan and Musteen 2011; Sartor and Beamish 2014). Drawing a distinction between different 
uncertainties is important because they underpin firms' governance choices (Ashill and Jobber 2009).

Consistent with this view, Sartor and Beamish (2018) have advanced an uncertainty-based perspective which proposes that different types of corruption can be distinguished on the basis of the disparate uncertainties (environmental uncertainty versus behavioral uncertainty), the unique risks (knowledge-based risk versus opportunismbased risk) and the distinct costs (information search costs versus monitoring and enforcement costs) that they precipitate. More specifically, they propose that some varieties of host market corruption can be expected to primarily inhibit transparency in the foreign market which heightens environmental uncertainty and knowledge-based risk for the MNC. As such, the firm experiences increased information costs as it searches for the knowledge and information that it requires to operate in the foreign market. Conversely, other types of corruption can be expected to primarily inhibit trust in the foreign market and heighten behavioral uncertainty which increases the risk of opportunism and stimulates more pronounced monitoring and enforcement costs for the MNC. In turn, the disparate uncertainties precipitated by the distinct types of corruption are expected to exert different effects on the MNC's strategic choices. Notably, corruption researchers have identified an important conceptual distinction between public corruption and private corruption which motivates our application of this uncertainty-based framework. More specifically, Montiel et al. (2012, p. 1104) have observed that "government corruption undermines the rule of law and creates uncertainty in the enforcement of regulations... while private sector corruption reduces trust in private institutions and parties...".

Building on the foregoing, Table 1 summarizes how we expect that the differences between public and private corruption will be manifest in foreign markets. First, we focus on the primary impact of each type of corruption upon the host market (either inhibiting transparency or inhibiting trust). Second, we focus on the primary uncertainty (environmental or behavioral), risk (knowledge-based or opportunism-based) and costs (information search or monitoring and enforcement) that are associated with public corruption and private corruption. In turn, more pronounced levels of each type of host market corruption are expected to motivate different preferences with respect to a subsidiary's organizational structure. While we develop hypotheses with respect to our expectations regarding the distinct effects of public and private corruption upon the organizational structure of foreign subsidiary investments, we acknowledge that other factors such as the characteristics of the parent firm (Brouthers et al. 2003) are also salient determinants.

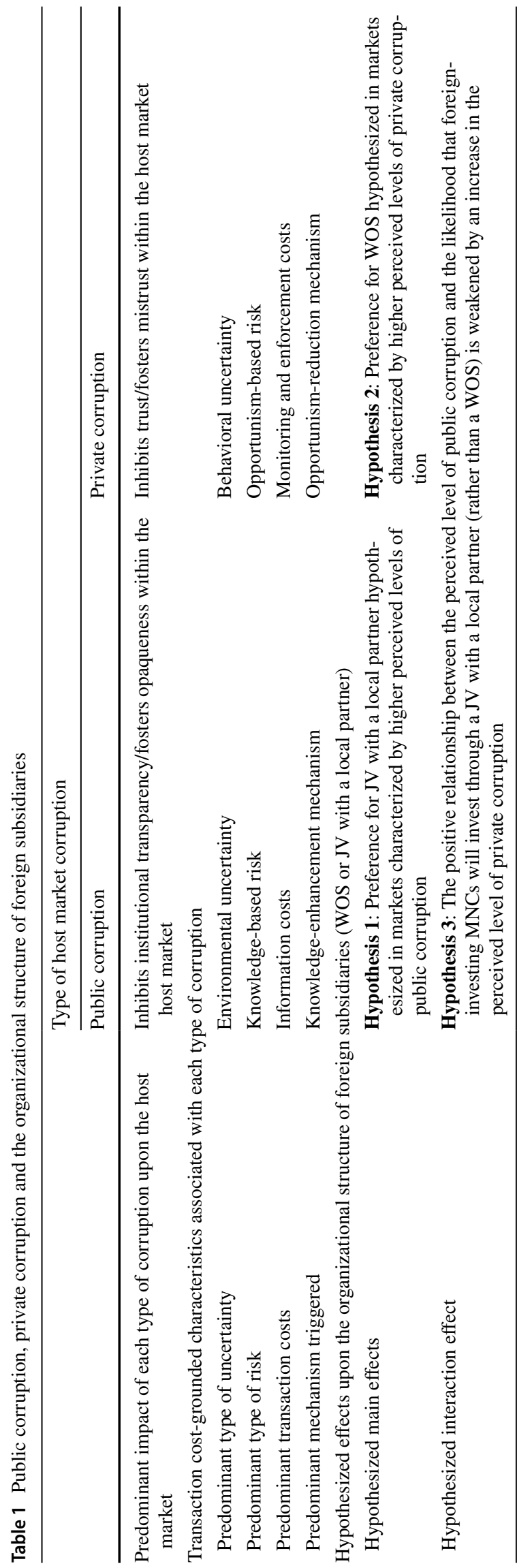




\section{Public Corruption and Organizational Structure}

When MNCs enter into a foreign market, they often need to interact with the host market's public officials to secure goods, services and other resources that are controlled by the state (Wan 2005). Permits, approvals, licenses, utilities, customs clearances, regulatory rulings, tax concessions, judicial decisions and procurement contracts are just a few of the many government-controlled goods and services that may be needed by the MNC to facilitate foreign entry or to sustain ongoing operations in the host market (Rose-Ackerman 1997). Public corruption occurs when government officials and bureaucrats leverage their ability to arbitrarily modify or alter the policies, regulations and procedures that govern the distribution of the state's goods, services and resources (Lambsdorff 2002b; Luo 2005). Consequently, we assume that public sector corruption inhibits institutional transparency and fosters environmental uncertainty due to the resultant ambiguity with respect to the host government's policies, regulations and procedures (Miller 1992). In turn, MNCs are exposed to increased knowledge-based risk in foreign markets characterized by heightened environmental uncertainty because public corruption exacerbates information uncertainty for the MNC (Javorcik and Wei 2009). More precisely, foreign-investing MNCs often find that they lack the knowledge and information that is required to navigate their interactions with government officials in more corrupt host market environments (Roy and Oliver 2009). Consequently, information costs will be more pronounced (Luo 2004) as MNCs endeavor to overcome heightened environmental uncertainty and knowledge-based risk in such markets. These "knowledge-based transaction costs" include the cost of identifying new sources of relevant knowledge and information, as well as the cost of absorbing this knowledge (Conner and Prahalad 1996, p. 484). As such, we expect that the relationship between public sector corruption and a foreign subsidiary's organizational structure will be grounded in a knowledge-enhancement mechanism.

When a MNC commits to investing in a foreign market characterized by more pronounced public corruption, the firm will consider a wide array of possible responses to corruption which range from outright compliance with corrupt local norms to outright avoidance of corrupt transactions in the host market (Søreide 2006). The MNC's choice will ultimately be contingent upon its understanding of how to manage corrupt practices in the local market (Doh et al. 2003). This comprehension is essential for the MNC because host market governments typically maintain monopolistic control over many of the critical resources (such as permits, licenses and other resources) that the MNC will need when entering and operating there (Buck et al. 1998; Shleifer and Vishny 1993). We have proposed that public corruption increases the costs of investing in a foreign market because corruption exploits the foreign-investing MNC's lack of knowledge with respect to operating in the host market (Meyer and Nguyen 2005). The need for local knowledge is particularly salient in countries that exhibit lower levels of institutional transparency (Xu and Meyer 2013). Scholars have theorized that when a firm wants to enhance its knowledge base in foreign markets, it can develop the knowledge organically over time through experience because a firm's prior experience is an important source of learning and it has been found to influence organizational structure (Powell and Rhee 2016). Alternatively, it can access the local market knowledge that is embedded in prospective collaborators (Madhok 1997). A host market equity partner can bolster the MNC's efforts to augment its local market knowledge in at least three important ways. First, a local partner can reduce or even eliminate the need for the MNC to interact with the government directly, allowing the MNC to rely entirely upon the partner's knowledge and experience (Doh et al. 2003). Second, the MNC can access the partner's knowledge of the local environment (Luo 2001). More specifically, an equity partner can teach the MNC how to bargain with government agents more effectively and efficiently (Rodriguez et al. 2005). Finally, a partner may help the MNC to integrate into local networks (Meyer et al. 2009). Inclusion in these networks enhances the bargaining power of the MNC because the reputations and repeated transactions that are associated with these networks are resources that can be leveraged to contain the information costs associated with bargaining with government officials (Lambsdorff 2002a). In this regard, leveraging a local partner's network and knowledge of corrupt institutions prevailing in the host country can position a foreign-investing firm to reduce informationbased transaction costs (Meschi 2009). Accordingly, we hypothesize,

Hypothesis 1 A higher perceived level of public corruption in a foreign host market will increase the likelihood that a MNC will structure its foreign subsidiary investment as a JV with a local partner.

\section{Private Corruption and Organizational Structure}

Management scholars and political scientists have observed that private sector corruption impairs societal trust (Montiel et al. 2012; Rothstein 2005). A firm's value chain is populated by a wide range of private sector stakeholders such as customers, suppliers, investors and employees (Pfarrer et al. 2008). The existence of trust throughout a firm's value chain confers a degree of confidence that exchange transactions will be executed as agreed upon and expected (Anokhin and Schulze 2009; Jung and Lee 2017). However, the prevalence of private corruption degrades both individual trust and collective trust (Ashforth et al. 2008), as well as undermining 
"predictability... and...mutually understood standards of behavior for exchange relationships" (Lange 2008, p. 718). Consequently, we assume that higher levels of private sector corruption in foreign countries inhibit trust and foster mistrust within those countries. In turn, MNCs are exposed to heightened behavioral uncertainty (Brouthers and Brouthers 2003; Noorderhaven 1996) and opportunism-based risk (Das and Teng 1996). Monitoring and enforcement costs will be more pronounced (Rose-Ackerman 2010) as MNCs endeavor to overcome the increased behavioral uncertainty and opportunism-based risk that they encounter when the level of private corruption is high. As such, we expect that the relationship between private sector corruption and a foreign subsidiary's organizational structure will be grounded in an opportunism-reduction mechanism.

Intuitively, some might speculate that a foreign-investing MNC will prefer a JV with a local firm in foreign markets characterized by heightened private corruption because a partner could help the MNC to learn how to manage private corruption in the host market. However, we expect that behavioral uncertainty and opportunism-based risk will be a more prominent concern for the MNC here. This is because MNCs engage in innumerable transactions in the private sector when entering an overseas market. Establishing foreign subsidiary operations "requires negotiations with... suppliers, distributors and customers, and a labor force needs to be hired and trained" (Guillén 2002, p. 511). While it is possible that a MNC might encounter private sector monopolies when executing some of these private sector transactions, a host market's private sector tends to offer a broad array of suppliers, customers, employees and other private sector stakeholders with which the MNC may transact (Calhoun 2002; Meyer 2004). This is very different from the monopolistic conditions that MNCs encounter with respect to the host government's goods, services and other resources (Shleifer and Vishny 1993). Consequently, we expect that any learning from a potential local JV partner with respect to managing private sector corruption in the host market will be limited by the challenge of bounded reliability (Verbeke and Asmussen 2016). More precisely, the potential learning benefits will be largely idiosyncratic and restricted to a relatively narrow range of private sector counterparties in the host market with which a prospective local JV partner may be familiar through prior commercial transactions. Moreover, a firm's prior experience in dealing with uncertainty and risk in a foreign market may be as important as a prospective partner's knowledge. In fact, MNCs routinely rely upon their prior experience to guide their decisions, strategy and behavior under conditions of uncertainty and risk (Jiménez et al. 2018).

Scholars have theorized that corporate corruption can be conceptualized as a "social trap" which cultivates societal mistrust that impedes individuals and organizations from being able to cooperate (Rothstein 2005). This is because corruption undermines the foundation upon which trust becomes generalized across a host market's constituents (Anokhin and Schulze 2009). Consequently, when a MNC enters into a foreign market characterized by heightened private corruption, the risk of opportunistic behavior can be expected to infiltrate its relationships with suppliers, customers and any prospective local JV partners (Hess 2009). Opportunistic parties generally tend to focus on their own interests which weakens the foundation for collaboration (Luo 2007). When trust is lacking, both the negotiation and execution of JV arrangements "will be subject to more formal and costly procedures than would occur under a regime of greater trust" (Williamson 1985, p. 293). As such, heightened levels of behavioral uncertainty will motivate MNCs to engage in efforts to lessen the risk of opportunism (Roy 2012). In turn, we expect that an opportunism-reduction mechanism underpins the relationship between the perceived level of private corruption in foreign host markets and the organizational structure of foreign subsidiaries. Scholars have theorized that when a firm wants to reduce its exposure to the risk of opportunism in foreign markets, it may internalize transactions and protect itself from the costs of transacting with a partner (Madhok 1997). In fact, when prospective partners pose a high risk of opportunistic behavior in foreign markets, MNCs will prefer to invest through a structure that offers maximum control over the subsidiary (Dikova and van Witteloostuijn 2007). As such, we hypothesize that,

Hypothesis 2 A higher perceived level of private corruption in a foreign host market will increase the likelihood that a MNC will structure its foreign subsidiary investment as a WOS.

\section{Interaction Effect: Public Corruption, Private Corruption and Organizational Structure}

Transaction cost theory has traditionally focused upon the governance choice that minimizes opportunism-based transaction costs (Conner and Prahalad 1996; Madhok 1997). However, scholars have advocated the need to integrate established transaction cost tenets with knowledgeand learning-oriented concepts (Rugman and Verbeke 2003). Our disaggregation of the host market corruption construct into its public and private components, in addition to our hypotheses which posit the distinct impact of each upon a foreign subsidiary's organizational structure, implicitly suggest that an interaction effect between the two types of corruption may influence the foreign entry decisions of MNCs. As Table 1 indicates, the mechanisms that underpin our work are grounded in the distinct uncertainties, risks and costs associated with each type of 
corruption. Paradox theorists have noted that when a firm engages in decisions with respect to how to structure its operations, contradictory pressures become increasingly salient (Smith and Lewis 2011). The conflicting demands of public and private corruption in the host market complicate a MNC's efforts to devise its foreign entry strategy and illuminate competing concerns regarding the utility versus the riskiness of a local partner.

In practice, we anticipate that a foreign-investing MNC will be particularly focused upon the level of public corruption in the context of its governance choice when planning its foreign entry. We attribute this to the substantial environmental uncertainty and knowledge-based risk that can be precipitated by the bureaucratic exercise of discretionary power and monopolistic control over the government resources that the MNC needs in the foreign host market (Shleifer and Vishny 1993). Public corruption is a consequential complicating factor for MNCs that choose to enter into foreign markets (Javorcik and Wei 2009). The adverse impact of public corruption upon the financial performance (Petrou 2015) and survival (Meschi 2009) of foreign subsidiary investments has been well documented by both academic researchers and the media (The Economist 2010). As such, a compelling imperative exists to motivate the MNC to focus its strategic efforts upon learning how to handle heightened public corruption in foreign markets. To enhance its knowledge base, we have proposed that the MNC will be more likely to invest through a JV with a local partner in such markets. In this context, we expect that "knowledge-based considerations" will "outweigh opportunism-related ones" when the MNC evaluates its governance options (Conner and Prahalad 1996, p. 479).

However, a direct consequence of the MNC's preliminary attentiveness to the level of public corruption is that the choice to minimize the "cost of information...can increase...(the) cost of opportunistic betrayal" (Buckley and Chapman 1997, p. 134). Transaction cost logic is fundamentally motivated by the cost-reduction objective (Williamson 1985). As such, we expect that competing transaction cost-based considerations are unlikely to permit the unfettered exercise of uncertainty trade-offs in the context of foreign market entry. Instead, the MNC will be compelled to balance its efforts to minimize both "opportunism-based transaction costs" and "knowledge-based transaction costs" (Conner and Prahalad 1996, p. 492). This is because "both transaction cost considerations and learning effects influence strategy selection" (Verbeke 2003 , p. 502). In fact, given that cooperative strategies designed to reduce environmental uncertainties can progressively expose the MNC to an increased risk of opportunistic behavior by the cooperating partner (Miller 1992), we expect that heightened private corruption will negatively moderate the relationship between public corruption and the organizational structure of a foreign subsidiary. Accordingly, we hypothesize that,

Hypothesis 3 The positive relationship between the level of public corruption and the likelihood that a MNC will structure its foreign subsidiary investment as a JV with a local partner will be weakened by an increase in the level of private corruption.

\section{Methods}

\section{Data Sources and Focal Independent Variables}

Our sample was constituted by 187 subsidiaries established in 19 foreign markets between 2005 and 2008. The 19 host countries included (the number of subsidiary investments established follows the country name in brackets): France (6), Germany (8), Hong Kong (13), India (20), Italy (1), South Korea (24), Malaysia (4), Mexico (2), Netherlands (11), Philippines (7), Poland (3), Russia (4), Singapore (12), South Africa (1), Taiwan (13), Thailand (23), Turkey (1), United Kingdom (4) and United States (30). The corporate data were obtained from the Kaigai Shinshutsu Kigyou Souran database which reports on the worldwide foreign subsidiary investment activity of Japanese MNCs. Our observations with respect to the dependent variable were lagged by 1 year relative to the observations with respect to our measures of the perceived levels of private corruption and public corruption. We employed Transparency International's Global Corruption Barometer (GCB) database to constitute our measures of private and public corruption. These data were reported by Transparency International for a period of 4 consecutive years (2004-2007), following which the GCB surveys and the collection of some of the constituent indicators have been executed more intermittently, rather than on a regular annual basis. As such, the availability of this country-level data determined the study period, the host countries and our sample of foreign subsidiary investments.

\section{Private Corruption and Public Corruption}

The GCB database reports on the extent to which the general public perceives that various sectors in the country are affected by corruption. The lack of prior research pertaining to private corruption has traditionally been attributed to the shortage of longitudinal data with respect to the level of private corruption in host countries (Rose-Ackerman 2007). However, scholars have recently developed a measure of private corruption that employs the GCB database. Leveraging this data, Gutmann and Lucas (2018) have proposed that the level of private corruption in a country can be measured in terms of the public's perceptions with respect to the 
prevalence of corruption in businesses, NGOs, media and religious bodies. Scores range between 1 (not at all corrupt) and 5 (extremely corrupt). We subjected the GCB's corruption data for these four sectors, along with data for three other sectors reported in the GCB (corruption in the police, political parties and tax revenue) to a principal components analysis with a varimax rotation. Consistent with Gutmann and Lucas' (2018) conceptualization and measurement of private corruption, businesses $(0.765)$, NGOs $(0.773)$, media $(0.857)$ and religious bodies $(0.839)$ all loaded on one component which we named private corruption. The police (0.963), political parties (0.853) and tax revenue (0.784) all loaded on the second component which we named public corruption. The two components explained $80.05 \%$ of the variance in the data and the Cronbach's alpha for private corruption (0.859) and public corruption (0.908) both exceeded the 0.70 cut-off (Nunnally and Bernstein 1994). The public corruption measure was computed by calculating the average of the three items (police, political parties and tax revenue), while the private corruption measure was calculated by computing the average of the four remaining items (business, NGOs, media and religious bodies). As an example, given that observations with respect to the dependent variable were lagged by 1 year relative to the observations with respect to the perceived levels of corruption, for a subsidiary established in France during 2005, the public corruption measure (3.23) was computed by averaging the results reported by the GCB for France for 2004 with respect to corruption in the police (3.1), political parties (4.1) and tax revenue (2.5). Similarly, averaging the GCB results reported for corruption in businesses (3.5), NGOs (2.5), media (3.5) and religious bodies (2.2) in France yielded the private corruption measure (2.93).

\section{Dependent Variable, Control Variables and Estimation Methods}

\section{Dependent Variable (Organizational Structure)}

We investigate the impact of public and private corruption upon a MNC's organizational structure (the choice between a WOS and a JV with a local partner). Prior empirical work has employed different equity ownership cut-off conventions to distinguish between a WOS (coded " 0 " in our study) and a JV with a local partner (coded " 1 " in our study). We employed the $80,90,95$ and $100 \%$ equity ownership cutoff conventions to distinguish between WOSs and JVs in our sample (Park and Ungson 1997; Yiu and Makino 2002). We report the results of our estimations using the $100 \%$ convention in Tables 3 and 4 . We present the results using the 80,90 and $95 \%$ conventions as robustness tests in the "Robustness Estimations" section. Using the $80 \%$ cut-off, $80.7 \%$ of the subsidiary investments were categorized as
WOSs and $19.3 \%$ as JVs with a local partner. When the 90\% equity ownership cut-off convention was employed, 80.2 and $19.8 \%$ were categorized as WOSs and JVs with a local partner respectively, while the $95 \%$ cut-off yielded a sample in which $78.9 \%$ of the subsidiaries were WOSs and $21.1 \%$ were JVs with a local partner. Finally, $78.7 \%$ were WOSs and $21.3 \%$ were JVs with a local partner using the $100 \%$ cut-off.

\section{Control Variables}

Variables were included to control for other effects which have been found to influence a MNC's decisions with respect to the organizational structure of its foreign subsidiaries. The subsidiary's relative size was operationalized using a ratio of the subsidiary's total capital to the MNC's total assets. The parent MNC's experience, size and profitability are also important determinants of a MNC's governance choice for its subsidiary investment (Brouthers et al. 2003). We controlled for the parent's host market experience using the MNC's total number of subsidiary years of prior experience in the host market. Parent size was measured using the MNC's total sales, while profitability was operationalized with the firm's return on assets. We included a set of dummies to account for the year in which the subsidiary investment was established (Reuer and Ragozzino 2014). A dummy variable was also used to distinguish between service industry and manufacturing industry firms because a firm's industry designation has also been found to be an important determinant of organizational design decisions (Brouthers and Brouthers 2003). A host market's economic, institutional and cultural conditions are well-established predictors of a MNC's organizational structure. We measured host market size using the gross domestic product for each country (Uhlenbruck et al. 2006; Voyer and Beamish 2004). Further, a host market's economic growth prospects contribute to its environmental risk profile and impact the foreign entry decisions of MNCs (Schwens et al. 2011). We operationalized host market growth rate using the percentage change in real gross domestic product based on national currency in constant prices (Habib and Zurawicki 2002). Foreign direct investment (FDI) restrictions (Gomes-Casseres 1990) was based upon data from the Heritage Foundation's Economic Freedom Index database. Policy stability was measured using the most recent value prior to foreign entry available from Henisz's (2002) data. Robustness estimations using the risk of political instability indicator data from IMD's World Competitiveness Yearbooks produced substantially similar results in terms of the sign $( \pm)$ and the significance of the public and private corruption main effects across all of the models. The cultural distance covariate was based upon data from the World Values Survey (WVS) 
(Chipulu et al. 2018; Ralston et al. 2011). We employed Berry et al.'s (2010) measure which uses the WVS database to compute the cultural distance between countries. Skewed covariates (subsidiary size, host market size, parent MNC size and profitability) were log transformed (Tabachnick and Fidell 2007).

\section{Estimation Methods}

Multilevel data structures exist when outcomes at a lower (individual)-level are nested within a higher (group)-level such that the lower-level outcomes are predicted by both lower-level and higher-level independent variables (Liu 2015). Given that the lower-level outcomes occur within higher-level groups, it can be important to allow for the correlations among the observations for lower-level units that belong to the same higher-level group (Rabe-Hesketh and Skrondal 2008). When higher (group)-level information is disaggregated to the lower (individual)-level and all predictors are associated with the lower unit of analysis, researchers overlook the possibility that individuals from the same group may have correlated errors (Luke 2004). As such, multilevel logistic regression models facilitate the efforts of researchers to investigate data structures with variables that span different levels of analysis and to simultaneously estimate relationships between predictors from multiple levels and the binary outcome variable (Liu 2015).

Notably, sample size guidelines for multilevel regression models vary (Schoeneberger 2016). Some researchers advocate in favour of the need to employ relatively large sample sizes to execute these models and estimate the effects accurately (Hoffmann et al. 2000; Schoeneberger 2016). However, other scholars maintain that multilevel models can be estimated using unbalanced samples (Peterson et al. 2012) with as few as one to two observations per group (Bell et al. 2008). Given that some of the countries in our sample hosted a smaller number of subsidiary investments relative to other countries in our sample, we report results using multilevel logistic regression (Table 3), as well as ordinary logistic regression (Table 4) as a robustness test (Rabe-Hesketh and Skrondal 2008).

In both Tables, Model 1 is a base model which includes all the control variables but excludes the effects of public and private corruption. We then estimated models (Models 2 and 3) which introduce the effects of public corruption and private corruption separately, before presenting Model 4 which includes both main effects together. Hypothesis 3 pertaining to the interaction effect was tested in Model 5 which also includes the main effects of both types of corruption. As such, while Hypothesis 1 with respect to the main effect of public corruption was tested in Models 2, 4 and 5, Hypothesis 2 with respect to the main effect of private corruption was tested in Models 3, 4 and 5. WOS was designated as the reference category in all the models.

\section{Results}

Table 2 provides descriptive statistics and Table 3 presents the results of the multilevel logistic regression estimations. The highest variance inflation factor (VIF) score (3.79) reported for our models in Table 3 is less than the benchmark value of 10 (Tabachnick and Fidell 2007) and the average VIF across all of our models is 2.04. Further, none of the correlations between the variables in our models exceed the 0.70 threshold (Tabachnick and Fidell 2007). Accordingly, we concluded that multicollinearity was not a concern in our regression estimations.

In Table 3, we present the base model which excludes the effects of the two focal corruption variables, along with the models that include the main effects and the interaction effect associated with public and private corruption. Consistent with the expectations posed in Hypothesis 1, the results presented in Model 2 which introduces public corruption alone indicate that this main effect is a significant predictor of a foreign subsidiary's organizational structure (Model 2: $\beta=1.31, p<0.05)$. The results suggest that higher perceived levels of public corruption increase the likelihood that MNCs will invest through a JV with a local partner, rather than a WOS. Model 3 presents the results when private corruption alone is added to the base model to test Hypothesis 2 . The results indicate that the main effect of private corruption is also a significant predictor of a subsidiary's organizational structure (Model 3: $\beta=-2.60, p<0.10$ ). Firms are more likely to employ a WOS investment structure to facilitate entry into foreign host markets characterized by heightened perceived levels of private corruption. To investigate the effects of both types of corruption simultaneously, Model 4 introduces the main effects of both public and private corruption. Consistent with the expectations posed by Hypotheses 1 and 2, more pronounced perceived levels of public corruption continued to predict an increased likelihood that a MNC would invest through a JV with a local partner (Model 4: $\beta=3.32, p<0.01$ ). Conversely, higher perceived levels of private corruption precipitated the opposite outcome, namely, an increased likelihood of structuring the foreign subsidiary investment as a WOS (Model 4: $\beta=$ $-6.74, p<0.05)$.

Finally, the results associated with Model 5 which tests Hypothesis 3 reveal that the interaction effect between public and private corruption does not have a statistically significant impact upon the structure of a MNC's foreign subsidiary investments $(\beta=2.12, \mathrm{p}>0.10)$. However, the results with respect to the main effects of public (Model 5: $\beta=3.88, p<0.05$ ) and private corruption (Model 5: $\beta=$ $-7.77, p<0.05)$ are consistent with the outcomes predicted in Hypotheses 1 and 2. As such, while Hypotheses 1 and 2 are supported by the results presented in Models 2, 3, 4 and 
Table 2 Descriptive statistics and correlations

\begin{tabular}{|c|c|c|c|c|c|c|c|c|c|}
\hline Variable & Mean & $\mathrm{SD}$ & 1 & 2 & 3 & 4 & 5 & 6 & 7 \\
\hline 1. Organizational structure ${ }^{a}$ & 0.21 & 0.41 & & & & & & & \\
\hline 2. Subsidiary size & -2.88 & 1.36 & -0.02 & & & & & & \\
\hline 3. Parent size & 5.18 & 0.91 & 0.12 & -0.60 & & & & & \\
\hline 4. Parent profitability & -1.28 & 0.35 & -0.09 & -0.06 & -0.14 & & & & \\
\hline 5. Parent host market experience ${ }^{b}$ & 0.17 & 0.52 & 0.17 & -0.37 & 0.57 & -0.07 & & & \\
\hline 6. Entry year dummy (2005) & 0.26 & 0.44 & -0.19 & -0.12 & 0.07 & 0.08 & -0.07 & & \\
\hline 7. Entry year dummy (2006) & 0.32 & 0.47 & -0.06 & 0.01 & -0.05 & 0.03 & 0.00 & -0.41 & \\
\hline 8. Entry year dummy (2007) & 0.24 & 0.43 & 0.16 & -0.01 & -0.04 & 0.15 & 0.04 & -0.34 & -0.38 \\
\hline 9. Industry dummy & 0.22 & 0.42 & 0.12 & 0.07 & -0.02 & -0.01 & -0.01 & -0.02 & -0.02 \\
\hline 10. Host market size & 2.89 & 0.65 & -0.11 & -0.11 & -0.02 & 0.12 & 0.20 & 0.05 & -0.06 \\
\hline 11. Host market growth rate & 5.21 & 2.33 & 0.14 & 0.08 & 0.16 & -0.24 & -0.10 & 0.07 & -0.16 \\
\hline 12. FDI restrictions & 30.22 & 22.43 & -0.01 & 0.00 & 0.10 & 0.01 & 0.01 & -0.09 & 0.05 \\
\hline 13. Policy stability & 0.38 & 0.19 & 0.00 & -0.05 & 0.07 & 0.09 & -0.02 & -0.16 & 0.02 \\
\hline 14. Cultural distance & 16.21 & 9.17 & -0.08 & 0.05 & -0.05 & 0.02 & 0.07 & 0.03 & -0.03 \\
\hline 15. Public sector corruption & 3.37 & 0.59 & 0.20 & -0.07 & 0.18 & -0.11 & 0.04 & -0.20 & -0.01 \\
\hline 16. Private sector corruption & 2.88 & 0.31 & -0.06 & -0.17 & 0.00 & 0.04 & 0.13 & -0.15 & -0.14 \\
\hline 17. Public corruption $\times$ private corruption & 0.10 & 0.24 & -0.10 & -0.12 & 0.16 & -0.02 & 0.04 & 0.20 & -0.06 \\
\hline Variable & 8 & 9 & 10 & 11 & 12 & 13 & 14 & 15 & 16 \\
\hline 9. Industry dummy & 0.08 & & & & & & & & \\
\hline 10. Host market size & 0.04 & 0.04 & & & & & & & \\
\hline 11. Host market growth rate & -0.03 & -0.07 & -0.54 & & & & & & \\
\hline 12. FDI restrictions & -0.02 & 0.04 & -0.14 & 0.16 & & & & & \\
\hline 13. Policy stability & 0.15 & 0.06 & 0.46 & -0.22 & 0.44 & & & & \\
\hline 14. Cultural distance & -0.02 & 0.00 & 0.06 & -0.15 & -0.03 & -0.29 & & & \\
\hline 15. Public sector corruption & 0.06 & 0.05 & 0.08 & 0.15 & 0.12 & 0.52 & -0.24 & & \\
\hline 16. Private sector corruption & 0.23 & -0.04 & 0.57 & -0.34 & -0.25 & 0.42 & -0.21 & 0.48 & \\
\hline 17. Public corruption $\times$ private corruption & -0.08 & -0.12 & -0.26 & 0.38 & -0.06 & -0.40 & -0.22 & -0.44 & -0.20 \\
\hline
\end{tabular}

Correlations with an absolute value equal to or greater than 0.15 are statistically significant at the $p<0.05$ level

All are two-tailed tests

${ }^{a}$ Wholly owned subsidiary or joint venture with a local partner

${ }^{\mathrm{b}}$ Re-scaled $10^{-3}$

5, Hypothesis 3 is not supported. Taken together, the nonsignificance of the interaction effect in Model 5, coupled with the significance of the public and private corruption main effects in Models 2, 3, 4 and 5 of Table 3, suggest that public and private corruption do not interact to impact upon the organizational structure of a MNC's foreign subsidiary investment. Instead, the results reveal that it is the main effects of these conflicting forces that ultimately influence the organizational structure of foreign subsidiaries that are established in more corrupt host markets. The results also reveal that Model 4 exhibits the lowest Akaike information criterion (185.75) (Burnham and Anderson 2004; Liu 2015).

\section{Robustness Estimations}

To test the robustness of the results reported in Table 3, we executed additional models using the 80,90 and $95 \%$ equity ownership cut-off conventions that have been used in the literature to distinguish between WOSs and JVs (Park and Ungson 1997; Yiu and Makino 2002). Employing these alternate conventions, the results were substantially similar in terms of the sign $( \pm)$ and the significance of the main effects of public corruption and private corruption across all of the models, with the primary exception being that the main effect of private corruption became significant at the $p<0.01$ level in Model 4 when the $80 \%$ cut-off convention was used.

We also investigated the possibility that two of the sectors that are incorporated into the measure of private corruption 
Table 3 Results of multilevel logistic regression analyses of public corruption and private corruption on the organizational structure of foreign subsidiaries

\begin{tabular}{|c|c|c|c|c|c|}
\hline \multirow[t]{3}{*}{ Variables } & \multicolumn{5}{|c|}{ Organizational structure $^{\mathrm{a}}$} \\
\hline & Base model & Main effects & Main effects & Main effects & Interaction effect \\
\hline & Model 1 & Model 2 & Model 3 & Model 4 & Model 5 \\
\hline Intercept & $-1.46(0.58)^{*}$ & $-1.71(0.59)^{* *}$ & $-1.38(0.62)^{*}$ & $-2.02(0.80)^{*}$ & $-2.18(0.85)^{*}$ \\
\hline Subsidiary size & $0.14(0.25)$ & $0.21(0.23)$ & $0.12(0.23)$ & $0.13(0.24)$ & $0.12(0.24)$ \\
\hline Parent size & $0.25(0.59)$ & $0.35(0.48)$ & $0.43(0.59)$ & $0.38(0.51)$ & $0.36(0.51)$ \\
\hline Parent profitability & $-0.02(0.97)$ & $-0.07(0.98)$ & $0.04(0.98)$ & $0.02(0.96)$ & $0.09(0.98)$ \\
\hline Parent host market experience & $0.60(0.97)$ & $0.34(0.80)$ & $0.29(0.97)$ & $0.36(0.96)$ & $0.39(0.97)$ \\
\hline Industry dummy & $0.78(0.60)$ & $0.87(0.52)^{\mathrm{t}}$ & $0.78(0.54)$ & $0.80(0.56)$ & $0.83(0.56)$ \\
\hline Entry year dummy (2005) & $-2.38(3.58)$ & $-5.60(4.53)$ & $-5.89(8.03)$ & $-7.45(4.19)^{\mathrm{t}}$ & $-8.16(4.24)^{\mathrm{t}}$ \\
\hline Entry year dummy (2006) & $-0.62(0.64)$ & $-0.46(0.63)$ & $-0.96(0.68)$ & $-1.14(0.72)$ & $-1.33(0.78)^{\mathrm{t}}$ \\
\hline Entry year dummy (2007) & $0.37(0.68)$ & $0.60(0.68)$ & $0.53(0.73)$ & $1.18(0.86)$ & $1.21(0.88)$ \\
\hline Host market size & $-0.81(1.17)$ & $-0.13(0.74)$ & $0.04(0.84)$ & $2.05(1.31)$ & $2.06(1.26)$ \\
\hline Host market growth rate & $0.11(0.13)$ & $0.12(0.15)$ & $0.08(0.14)$ & $0.13(0.19)$ & $0.02(0.25)$ \\
\hline FDI restrictions & $-0.02(0.02)$ & $-0.01(0.01)$ & $-0.02(0.02)$ & $-0.03(0.02)$ & $-0.03(0.02)$ \\
\hline Policy stability & $0.46(3.41)$ & $-3.55(2.88)$ & $0.69(2.40)$ & $-6.21(3.87)$ & $-5.28(4.03)$ \\
\hline Cultural distance & $-0.02(0.03)$ & $-0.03(0.03)$ & $-0.05(0.04)$ & $-0.13(0.07)^{\mathrm{t}}$ & $-0.13(0.07)^{\mathrm{t}}$ \\
\hline Public sector corruption & & $1.31(0.63)^{*}$ & & $3.32(1.23)^{* *}$ & $3.88(1.54)^{*}$ \\
\hline Private sector corruption & & & $-2.60(1.44)^{t}$ & $-6.74(2.88)^{*}$ & $-7.77(3.29)^{*}$ \\
\hline Public corruption $\times$ private corruption & & & & & $2.12(3.04)$ \\
\hline Variance inflation factor range & $1.03-2.66$ & $1.03-3.36$ & $1.04-3.00$ & $1.06-3.40$ & $1.06-3.79$ \\
\hline Average variance inflation factor & 1.86 & 1.91 & 1.98 & 2.09 & 2.35 \\
\hline Model deviance & 156.38 & 151.45 & 152.15 & 137.75 & 137.26 \\
\hline$\Delta$ deviance $^{\mathrm{b}}$ & & 4.93 & 4.23 & 18.63 & 19.12 \\
\hline AIC & 200.38 & 197.45 & 198.15 & 185.75 & 187.26 \\
\hline$\Delta \mathrm{AIC}^{\mathrm{c}}$ & 14.63 & 11.70 & 12.40 & 0.00 & 1.51 \\
\hline
\end{tabular}

All are two-tailed tests. Standard errors are in rounded parentheses

${ }^{\mathrm{t}} p<0.10 ; * p<0.05 ; * * p<0.01 ; * * * p<0.001$

${ }^{a}$ The dependent variable organizational structure is coded as follows: 0: wholly owned subsidiary; 1: joint venture with a local partner

${ }^{\mathrm{b}}$ Compared to Model 1 (base)

${ }^{\mathrm{c}} \mathrm{AIC} \mathrm{Model}_{i}-$ minimum AIC

(media and religious bodies) may not be purely private sector entities in some of the 19 countries that we study. To do so, we leveraged prior cross-country research pertaining to government involvement in religious organizations and media organizations (Barro and McCleary 2005; Djankov et al. 2003). We determined that some of the subsidiary investments in our sample were established in a country with a state religion during our study period (i.e., Protestantism in the United Kingdom; Catholicism in Italy; Buddhism in Thailand, etc.) (Barro and McCleary 2005) and some were established in a country within which the top five daily newspapers were not owned entirely by private sector individuals and entities (Djankov et al. 2003). Therefore, as a robustness check on our results, we re-executed each of the models reported in Table 3 using a two-item measure of private sector corruption which was constituted by the indicators of corruption pertaining to businesses and NGOs (and excluded the items pertaining to the media and religious bodies). Employing the two-item measure of private sector corruption, the results were substantially similar in terms of the sign $( \pm)$ and the significance of the main effects of public corruption and private corruption across all of the models, with the primary exception being that the main effect of public corruption became significant at the $p<0.01$ level in Model 5.

As discussed in the "Estimation Methods" section, we also tested whether our results were robust to an alternate regression method. Table 4 presents the results of the ordinary logistic regression models that were estimated as a robustness check on the multilevel logistic regression results that are reported in Table 3. As Table 4 indicates, the results were substantially similar to the results reported in Table 3 in terms of the sign $( \pm)$ and the significance of the main effects of public corruption and private corruption across all 
Table 4 Results of ordinary logistic regression analyses of public corruption and private corruption on the organizational structure of foreign subsidiaries

\begin{tabular}{|c|c|c|c|c|c|}
\hline \multirow[t]{3}{*}{ Variables } & \multicolumn{5}{|c|}{ Organizational structure $^{\mathrm{a}}$} \\
\hline & Base model & Main effects & Main effects & Main effects & Interaction effect \\
\hline & Model 1 & Model 2 & Model 3 & Model 4 & Model 5 \\
\hline Intercept & $1.07(2.55)$ & $-2.23(3.03)$ & $5.75(3.69)$ & $4.65(3.87)$ & $-0.32(2.74)$ \\
\hline Subsidiary size & $0.02(0.19)$ & $0.05(0.19)$ & $-0.05(0.19)$ & $-0.10(0.20)$ & $-0.10(0.21)$ \\
\hline Parent size & $-0.03(0.36)$ & $-0.01(0.36)$ & $-0.10(0.37)$ & $-0.14(0.38)$ & $-0.14(0.39)$ \\
\hline Parent profitability & $-0.03(0.63)$ & $0.04(0.63)$ & $-0.05(0.63)$ & $0.07(0.65)$ & $0.07(0.65)$ \\
\hline Parent host market experience & $1.07(0.51)^{*}$ & $1.00(0.51)^{t}$ & $1.14(0.51)^{*}$ & $1.09(0.53)^{*}$ & $1.09(0.53)^{*}$ \\
\hline Industry dummy & $0.69(0.45)$ & $0.65(0.46)$ & $0.59(0.46)$ & $0.47(0.48)$ & $0.47(0.48)$ \\
\hline Entry year dummy (2005) & $-1.57(0.72)^{*}$ & $-1.38(0.72)^{t}$ & $-1.95(0.77)^{*}$ & $-1.73(0.77)^{*}$ & $-1.73(0.77)^{*}$ \\
\hline Entry year dummy (2006) & $-0.75(0.58)$ & $-0.64(0.59)$ & $-1.05(0.61)^{\mathrm{t}}$ & $-1.15(0.64)^{t}$ & $-1.15(0.65)^{\mathrm{t}}$ \\
\hline Entry year dummy (2007) & $0.03(0.58)$ & $0.24(0.61)$ & $-0.03(0.59)$ & $0.48(0.67)$ & $0.48(0.67)$ \\
\hline Host market size & $-0.92(0.57)$ & $-0.73(0.59)$ & $-0.60(0.59)$ & $0.43(0.76)$ & $0.44(0.77)$ \\
\hline Host market growth rate & $0.13(0.11)$ & $0.13(0.12)$ & $0.10(0.11)$ & $0.12(0.14)$ & $0.12(0.17)$ \\
\hline FDI restrictions & $-0.01(0.01)$ & $-0.01(0.01)$ & $-0.02(0.01)^{\mathrm{t}}$ & $-0.02(0.01)^{t}$ & $-0.02(0.01)^{\mathrm{t}}$ \\
\hline Policy stability & $1.42(1.72)$ & $-0.89(2.17)$ & $2.46(1.82)$ & $-1.95(2.59)$ & $-1.99(2.74)$ \\
\hline Cultural distance & $-0.02(0.03)$ & $-0.02(0.03)$ & $-0.03(0.03)$ & $-0.06(0.04)$ & $-0.06(0.04)$ \\
\hline Public sector corruption & & $1.00(0.49)^{*}$ & & $2.28(0.77)^{* *}$ & $2.25(0.91)^{*}$ \\
\hline Private sector corruption & & & $-1.78(1.04)^{\mathrm{t}}$ & $-4.38(1.59)^{* *}$ & $-4.35(1.72)^{*}$ \\
\hline Public corruption $\times$ private corruption & & & & & $-0.09(1.85)$ \\
\hline Variance inflation factor range & $1.03-2.66$ & $1.03-3.36$ & $1.04-3.00$ & $1.06-3.40$ & $1.06-3.79$ \\
\hline Average variance inflation factor & 1.86 & 1.91 & 1.98 & 2.09 & 2.35 \\
\hline$X^{2}$ & $26.21 *$ & $30.86^{* *}$ & $29.50 * *$ & $42.65 * * *$ & $42.65 * * *$ \\
\hline Pseudo $R^{2}$ ( $\Delta R^{2}$ compared to Base Model) & 0.14 & $0.17(0.03)$ & $0.16(0.02)$ & $0.23(0.09)$ & $0.23(0.09)$ \\
\hline
\end{tabular}

All are two-tailed tests. Standard errors are in rounded parentheses

${ }^{\mathrm{t}} p<0.10 ; * p<0.05 ; * * p<0.01 ; * * * p<0.001$

${ }^{a}$ The dependent variable organizational structure is coded as follows: 0: wholly owned subsidiary; 1: joint venture with a local partner

of the models. The primary exception to this is that the main effect of private corruption became significant at the $p<0.01$ level in Model 4. Further, some of the covariates (such as parent MNC host market experience and FDI restrictions) that were not significant in the multilevel models that are reported in Table 3 became significant in some of the binary logistic regression models reported in Table 4.

Finally, given the non-linear nature of logistic regression, the coefficients can be more challenging to interpret (Tabachnick and Fidell 2007). As such, we also assessed the substantive or practical significance of our results by calculating the predicted probabilities (Long and Freese 2014) of a MNC from our sample investing through a JV with a local partner at different perceived levels of private corruption and public corruption. We hypothesized a positive relationship between the perceived level of private corruption and the likelihood of a WOS (or conversely, a negative relationship between the perceived level of private corruption and the likelihood of a JV with a local partner). The results of the regression estimations supported this hypothesis. Consistent with this finding, the predicted probability of a MNC in our sample establishing a JV with a local partner at a perceived level of private corruption one standard deviation below the mean of private corruption was $43.9 \%$, whereas it was $10.9 \%$ at a perceived level of private corruption one standard deviation above the mean. We also hypothesized a positive relationship between the perceived level of public corruption and the likelihood of a JV with a local partner. Again, the results supported this hypothesis. Consistent with this finding, the predicted probability of a MNC from our sample establishing a JV with a local partner at a perceived level of public corruption one standard deviation below the mean of public corruption was $8.8 \%$, whereas it increased to $39.4 \%$ at a perceived level of public corruption one standard deviation above the mean.

\section{Discussion and Conclusions}

Both the UN's Global Compact and its SDGs implore stakeholders to work against all forms of corruption. Despite the urgency of this objective, corruption has persisted as an 
unrelenting global challenge that has been implicated as the root cause of numerous social and economic maladies. For example, economists have established that countries with high levels of corruption suffer from higher levels of poverty and income inequality because corruption reduces the resources available to fund public services such as education and healthcare (Gupta et al. 2002; Rose-Ackerman and Palifka 2016). Given that the International Monetary Fund (IMF) has recently estimated that the annual cost of bribery now amounts to approximately $2 \%$ of global gross domestic product (IMF 2016), a compelling imperative continues to motivate scholars' efforts to deepen our comprehension with respect to the nature of foreign host market corruption and its impact on the strategic and structural decisions of MNCs, in order to contribute to efforts to curb MNC engagement in foreign market corruption. As such, our research has asked: How do the perceived levels of public sector (government) corruption and private sector (non-government) corruption impact upon the organizational structure of a MNC's foreign subsidiaries?

Our research makes several contributions. First, building on ethics scholarship that has broadened the conceptualization of corruption (Argandoña 2003, 2017b; Gopinath 2008), we have examined the effects of both private and public corruption upon the strategic decisions of foreign-investing MNCs. Given that corruption taxonomies have primarily focused on public corruption, the narrow conceptualization of the construct has traditionally constrained the scope of research inquiry to the domain of bureaucratic activity. However, practical concerns are motivating the need to enhance our understanding of the private corruption construct. More specifically, achieving the targets established for the UN's SDGs is predicated upon the existence of sustained global economic growth (United Nations 2015). However, private corruption has been associated with both substantial declines in equity markets worldwide and subsequent global economic contractions on two separate occasions during the first decade of the twenty-first century (Ashforth et al. 2008; Tridico 2012; Weismann 2009). Equally-troubling, scholars have argued that private corruption engenders a wide range of adverse organizational consequences including, among others, lost revenues (Vadera et al. 2009), inefficient resource allocation (Green 2013) and the deterrence of capabilitybuilding (Luo 2005). In addition to amplifying the negative social, political and distributional effects of public corruption (Gopinath 2008), scholars have also proposed that private corruption may undermine shareholder value both indirectly, as a consequence of fines and penalties (Bishara and Schipani 2009), and directly through the depreciation of a firm's market capitalization (Narayanan et al. 2007). Our desire to focus more attention on private corruption may help to inform the development of managerial strategies that can be implemented to alleviate the adverse organizational effects of private corruption (Lambsdorff and Schulze 2015). Ultimately, "an understanding of private corruption is vital to any assessment of the role of business in society and of the effects of firms on the environment of corruption" (Rodriguez et al. 2006, p. 739).

Second, we have investigated how the perceived levels of private and public corruption each impact upon the organizational structure of a MNC's foreign subsidiaries. In addition to the practical urgency that we described above, our efforts have also been motivated by a sense of theoretical urgency. More specifically, scholars have proposed that the pervasiveness of host market corruption should influence a MNC's choice between two distinct organizational structures - a WOS and a JV with a local partner (Rodriguez et al. 2005). However, empirical studies have yielded conflicting results that have not fully substantiated this theoretically expected outcome (Asiedu and Esfahani 2001; Chang et al. 2012; Demirbag et al. 2007). Consequently, researchers have advocated in favor of more clearly elaborating the nature and effects of different types of corruption (Montiel et al. 2012), particularly public sector and private sector corruption (Argandoña 2003, 2017b; Gopinath 2008). As Montiel et al. (2012, p. 1105) have observed, corruption is a "complex phenomenon that requires more fine-grained research...distinguishing between different dimensions of corruption can contribute to our understanding of its effects on firm behavior."

We have contributed to this research agenda by applying an uncertainty-based perspective that is grounded in transaction cost theory (Sartor and Beamish 2018) to detail the different mechanisms through which public and private corruption can be expected to influence the organizational structure of foreign subsidiaries. We proposed that when MNCs encounter more pronounced corruption in foreign markets, public and private corruption can each be expected to exert distinct effects. Hypotheses were tested using a new measure of private sector corruption developed by Gutmann and Lucas (2018). We found that whereas more pronounced perceived levels of public corruption in foreign host countries motivated MNCs to prefer JVs with a local partner (rather than WOSs), heightened perceived levels of private sector corruption prompted MNCs to structure their foreign subsidiaries as WOSs. We attribute these distinct strategic responses to the different uncertainties and risks that underpin the relationship between the perceived level of each type of host market corruption and the organizational structure of an MNC's foreign subsidiary investment. More specifically, in the case of public corruption, environmental uncertainty and knowledge-based risk are the primary uncertainty and risk that influence the MNC's structural decision. Conversely, in the case of private corruption, behavioral uncertainty and opportunism-based risk predominate in shaping the MNC's preference. Our empirical findings and efforts 
to disaggregate host market corruption into both public and private corruption collectively help to clarify and improve our theoretical comprehension of the relationship between the perceived level of host market corruption and the organizational design decisions of foreign-investing MNCs.

Third, our research has built on the recent work of business ethics scholars who have become more focused upon enhancing our understanding of the various types of corruption that firms encounter in foreign markets (Luiz and Stewart 2014; Van Vu et al. 2018), as well as the different strategic, structural and operational responses of MNCs to heightened levels of corruption (Godinez and Liu 2018; Orudzheva et al. 2018; Xie et al. 2018). In doing so, we extend the body of business ethics scholarship (Clark and Brown 2015; Gago-Rodríguez et al. 2018; Gorsira et al. 2018; Hauser 2018; Remišová et al. 2018) that is generating theory to help inform the efforts of scholars who endeavor to design better corporate anti-corruption strategies and curb MNC engagement in overseas corruption. More specifically, our work contributes new insights which serve to broaden the set of assumptions that can be employed by anti-corruption researchers. Transaction cost-based anticorruption research conceptualizes corrupt acts as exchanges (Aidt 2003). Scholars have theorized that increasing the costs associated with engaging in these exchanges should reduce their prevalence (Bray 2005). As such, transaction cost researchers have identified a range of theoretically grounded strategies that should increase the costs associated with engaging in corruption. These include strategies designed to enhance monitoring, destabilize corrupt agreements and encourage betrayal among corrupt actors (Lambsdorff et al. 2005). However, assessments with respect to the efficacy of these transaction cost-grounded strategies in reducing the prevalence of $\mathrm{MNC}$ engagement in foreign market corruption have been mixed (Lambsdorff 2007; Rousso and Steves 2006). Heeks and Mathisen (2012) propose that the limited effectiveness of anti-corruption initiatives can be a consequence of design-reality gaps whereby theoretical assumptions embedded within the design of anti-corruption programs fail to accurately reflect the reality of the contexts within which these initiatives are deployed. We noted that two key assumptions have frequently underpinned the strategies and policy recommendations of anti-corruption theorists. First, corruption is conceptualized as occurring primarily within a MNC's public sector transactions with government officials and bureaucrats (Goel et al. 2015). Second, engaging a "middleperson" such as a JV partner is assumed to be a key strategy employed by MNCs to manage both the transactional uncertainty precipitated by more pronounced government corruption and the heightened transaction costs instigated by global anti-corruption efforts (Bray 2005; Drugov et al. 2014). However, these assumptions constitute important sources of potential misalignment between the design of an anti-corruption program and the context within which the program is deployed (Hansen 2011; Persson et al. 2013).

Our conceptual work and research findings suggest that policy prescriptions designed to curb MNC engagement in overseas corruption must consider both the multidimensional nature of the construct and the distinct strategic responses of MNCs to different types of corruption to ensure that anticorruption programs are properly calibrated. As such, the insights that emanate from our work contribute to the ethicsbased anti-corruption research agenda which has advocated in favor of "subscribing to a wider view of the definition of corruption" and developing "a more comprehensive understanding of how corruption impacts business" (Bishara and Schipani 2009, p. 766). Given the global pervasiveness of both private and public corruption, some researchers have recognized the importance of deterring both types of corruption (Goel et al. 2015; Rose-Ackerman 2010; Weismann et al. 2014). Our findings that public and private corruption each exert a distinct impact upon the structural decisions and partnering choices of MNCs suggest the need for increasingly multifaceted anti-corruption and corporate governance initiatives. In doing so, we bolster efforts to reduce the prevalence of design-reality gaps that threaten to undermine the efficacy of anti-corruption programs. In turn, our work serves to enhance the potential for scholars, policy makers and managers to curtail MNC engagement in overseas corruption. Further, improving our understanding of how MNCs respond to distinct types of corruption in foreign markets is ultimately intertwined with ongoing efforts to foster more responsible MNC leaders (Siegel 2014) whose actions can make a positive contribution to the achievement of the UN's full suite of sustainable development objectives.

\section{Limitations and Future Directions}

Notwithstanding our contributions, some limitations do exist. A first limitation is the use of a sample of firms from a single home country. While scholars have argued that this approach can be beneficial because it minimizes the impact of differences between multiple home countries upon the dependent variable (Coeurderoy and Murray 2008), future research should consider opportunities to verify our results with a sample of non-Japanese MNCs. Second, while our study is one of the first to employ the new measure of private corruption that has been developed by Gutmann and Lucas (2018), the geographic and temporal coverage of the measure's underlying data is still limited. As one example, private corruption data for our study period was not available for several countries including China, notwithstanding China's prominence as a global destination for FDI (World 
Investment Report 2017). Moreover, after 2007, the GCB surveys have been executed more intermittently, rather than on a regular annual basis.

Despite these limitations, the patterns that emerge from our research open new avenues for future scholarship. Different types of corruption have been found to exert distinct impacts upon the structure of a MNC's foreign subsidiaries. To extend our work, researchers should explore the effects of public and private corruption upon other decisions facing the MNC such as its expatriate assignment and asset deployment strategies. Additionally, the corporate social performance implications associated with adopting different organizational structures in more corrupt host market environments should also be investigated, with particular attention being given to the contingent effects associated with the distinct components of corruption that we have studied. Each of these lines of research inquiry holds the potential to augment the efforts of anti-corruption researchers, policy makers, MNCs and managers to address the pernicious challenge of overseas corruption.

\section{Compliance with Ethical Standards}

Conflict of interest The authors declared that they have no conflicts of interest.

Ethical Approval This article does not contain any studies with human participants or animals performed by any of the authors.

Open Access This article is distributed under the terms of the Creative Commons Attribution 4.0 International License (http://creativeco mmons.org/licenses/by/4.0/), which permits unrestricted use, distribution, and reproduction in any medium, provided you give appropriate credit to the original author(s) and the source, provide a link to the Creative Commons license, and indicate if changes were made.

\section{References}

Aguilera, R. V., \& Vadera, A. K. (2008). The dark side of authority: Antecedents, mechanisms, and outcomes of organizational corruption. Journal of Business Ethics, 77(4), 431-449.

Ahsan, M., \& Musteen, M. (2011). Multinational enterprises' entry mode strategies and uncertainty: A review and extension. International Journal of Management Reviews, 13(4), 376-392.

Aidt, T. S. (2003). Economic analysis of corruption: A survey. The Economic Journal, 113(8), F632-F652.

Anbarci, N., Escaleras, M., \& Register, C. A. (2009). The ill effects of public sector corruption in the water and sanitation sector. Land Economics, 85(2), 363-377.

Anokhin, S., \& Schulze, W. S. (2009). Entrepreneurship, innovation and corruption. Journal of Business Venturing, 24(5), 465-476.

Aravind, D., \& Christmann, P. (2011). Decoupling of standard implementation from certification: Does quality of ISO 14001 implementation affect facilities' environmental performance? Business Ethics Quarterly, 21(1), 73-102.
Argandoña, A. (2003). Private-to-private corruption. Journal of Business Ethics, 47(3), 253-267.

Argandoña, A. (2005). Corruption and companies: The use of facilitating payments. Journal of Business Ethics, 60(3), 251-264.

Argandoña, A. (2007). The United Nations Convention Against Corruption and its impact on international companies. Journal of Business Ethics, 74(4), 481-496.

Argandoña, A. (2017a). Petty corruption-Facilitating payments and grease money. In M. S. Aßländer \& S. Hudson (Eds.), The handbook of business and corruption: Cross-sectoral experiences (pp. 49-70). Bingley: Emerald Publishing Limited.

Argandoña, A. (2017b). Private and public corruption: Facilitating payments. In C. Rowley \& Marie dela Rama (Eds.), The changing face of corruption in the Asia Pacific: Current perspectives and future challenges (pp. 71-79). Cambridge: Elsevier.

Ashforth, B. E., Gioia, D. A., Robinson, S. L., \& Treviño, L. K. (2008). Re-viewing organizational corruption. Academy of Management Review, 33(3), 670-684.

Ashill, N. J., \& Jobber, D. (2009). Measuring state, effect, and response uncertainty: Theoretical construct development and empirical validation. Journal of Management, 36(5), $1278-1308$.

Asiedu, E., \& Esfahani, H. S. (2001). Ownership structure in foreign direct investment projects. Review of Economics and Statistics, 83(4), 647-662.

Azfar, O., \& Gurgur, T. (2008). Does corruption affect health outcomes in the Philippines? Economics of Governance, 9(3), 197-244.

Barro, R. J., \& McCleary, R. M. (2005). Which countries have state religions? Quarterly Journal of Economics, 120(4), 1331-1370.

Bell, B. A., Ferron, J. M., \& Kromrey, J. D. (2008). Cluster size in multilevel models: The impact of sparse data structures on point and interval estimates in two-level models. Paper presented at proceedings of the Joint Statistical Meetings, Survey Research Methods Section, Alexandria, VA.

Berry, H., Guillén, M. F., \& Zhou, N. (2010). An institutional approach to cross-national distance. Journal of International Business Studies, 41(9), 1460-1480.

Bishara, N., \& Schipani, C. (2009). Strengthening the ties that bind: Preventing corruption in the executive suite. Journal of Business Ethics, 88(4), 765-780.

Bray, J. (2005). The use of intermediaries and other alternatives to bribery. In J. Lambsdorff, M. Taube, \& M. Schramm (Eds.), The new institutional economics of corruption (pp. 93-111). New York: Routledge.

Brouthers, K. D., \& Brouthers, L. E. (2003). Why service and manufacturing entry mode choices differ: The influence of transaction cost factors, risk and trust. Journal of Management Studies, 40(5), 1179-1204.

Brouthers, K. D., Brouthers, L. E., \& Werner, S. (2003). Transaction cost-enhanced entry mode choices and firm performance. Strategic Management Journal, 24(12), 1239-1248.

Buck, T., Filatotchev, I., \& Wright, M. (1998). Agents, stakeholders and corporate governance in Russian firms. Journal of Management Studies, 35(1), 81-104.

Buckley, P., \& Chapman, M. (1997). The perception and measurement of transaction costs. Cambridge Journal of Economics, 21(2), 127-145.

Burnham, K. P., \& Anderson, D. R. (2004). Multimodel inference: Understanding AIC and BIC in model selection. Sociological Methods \& Research, 33(2), 261-304.

Calhoun, M. A. (2002). Unpacking liability of foreignness: Identifying culturally driven external and internal sources of liability for the foreign subsidiary. Journal of International Management, 8(3), 301-321.

Chang, Y.-C., Kao, M.-S., Kuo, A., \& Chiu, C.-F. (2012). How cultural distance influences entry mode choice: The contingent role of 
host country's governance quality. Journal of Business Research, 65(8), 1160-1170.

Chipulu, M., Marshall, A., Ojiako, U., \& Mota, C. (2018). Reasoned ethical engagement: Ethical values of consumers as primary antecedents of instrumental actions towards multinationals. Journal of Business Ethics, 147(1), 221-238.

Christmann, P., \& Taylor, G. (2001). Globalization and the environment: Determinants of firm self-regulation in China. Journal of International Business Studies, 32(3), 439-458.

Christmann, P., \& Taylor, G. (2006). Firm self-regulation through international certifiable standards: Determinants of symbolic versus substantive implementation. Journal of International Business Studies, 37(6), 863-878.

Clark, C., \& Brown, J. A. (2015). Multinational corporations and governance effectiveness: Toward a more integrative board. Journal of Business Ethics, 132(3), 565-577.

Coeurderoy, R., \& Murray, G. (2008). Regulatory environments and the location decision: Evidence from the early foreign market entries of new-technology-based firms. Journal of International Business Studies, 39(4), 670-687.

Conner, K. R., \& Prahalad, C. K. (1996). A resource-based theory of the firm: Knowledge versus opportunism. Organization Science, 7(5), 477-501.

Das, T. K., \& Teng, B. S. (1996). Risk types and inter-firm alliance structures. Journal of Management Studies, 33(6), 827-843.

De Colle, S., Henriques, A., \& Sarasvathy, S. (2014). The paradox of corporate social responsibility standards. Journal of Business Ethics, 125(2), 177-191.

dela Rama, M. (2012). Corporate governance and corruption: Ethical dilemmas of Asian business groups. Journal of Business Ethics, 109(4), 501-519.

Demirbag, M., Glaister, K. W., \& Tatoglu, E. (2007). Institutional and transaction cost influences on MNEs' ownership strategies of their affiliates: Evidence from an emerging market. Journal of World Business, 42(4), 418-434.

Dikova, D., \& van Witteloostuijn, A. (2007). Foreign direct investment mode choice: Entry and establishment modes in transition economies. Journal of International Business Studies, 38(6), 1013-1033.

Djankov, S., McLiesh, C., Nenova, T., \& Shleifer, A. (2003). Who owns the media? Journal of Law and Economics, 46(2), 341-382.

Doh, J. P., Rodriguez, P., Uhlenbruck, K., Collins, J., \& Eden, L. (2003). Coping with corruption in foreign markets. Academy of Management Executive, 17(3), 114-127.

Drugov, M., Hamman, J., \& Serra, D. (2014). Intermediaries in corruption: An experiment. Experimental Economics, 17(1), 78-99.

Eicher, T., García-Peñalosa, C., \& Van Ypersele, T. (2009). Education, corruption and the distribution of income. Journal of Economic Growth, 14(3), 205-231.

Feathers, B. (2014). Bribes without borders: The challenge of fighting corruption in the global context. American University International Law Review, 29(2), 287-292.

Gago-Rodríguez, S., Márquez-Illescas, G., \& Núñez-Nickel, M. (2018). Denial of corruption: Voluntary disclosure of bribery information. Journal of Business Ethics. https://doi.org/10.1007/s1055 1-018-3989-9.

George, G., Howard-Grenville, J., Joshi, A., \& Tihanyi, L. (2016). Understanding and tackling societal grand challenges through management research. Academy of Management Journal, 59(6), 1880-1895.

Geyskens, I., Steenkamp, J. B. E. M., \& Kumar, N. (2006). Make, buy or ally: A transaction cost theory meta-analysis. Academy of Management Journal, 49(3), 519-543.

Godinez, J., \& Liu, L. (2018). Corruption and its effects on FDI: Analysing the interaction between the corruption levels of the home and host countries and its effects at the decision-making level. Journal of Business Ethics, 147(4), 705-719.

Goel, R. K., Budak, J., \& Rajh, E. (2015). Private sector bribery and effectiveness of anti-corruption policies. Applied Economics Letters, 22(10), 759-766.

Gomes-Casseres, B. (1990). Firm ownership preferences and host government restrictions: An integrated approach. Journal of International Business Studies, 21(1), 1-22.

Gopinath, C. (2008). Recognizing and justifying private corruption. Journal of Business Ethics, 82(3), 747-754.

Gorman, T. O. (2013). Emerging trends in FCPA enforcement. Fordham International Law Journal, 37(4), 1193-1214.

Gorsira, M., Denkers, A., \& Huisman, W. (2018). Both sides of the coin: Motives for corruption among public officials and business employees. Journal of Business Ethics, 151(1), 179-194.

Green, S. (2013). Official and commercial bribery: Should they be distinguished? In J. Horder \& P. Alldridge (Eds.), Modern bribery law: Comparative perspectives (pp. 39-65). Cambridge: Cambridge University Press.

Grewatsch, S., \& Kleindienst, I. (2017). When does it pay to be good? Moderators and mediators in the corporate sustainability-corporate financial performance relationship: A critical review. Journal of Business Ethics, 145(2), 383-416.

Guillén, M. F. (2002). Structural inertia, imitation, and foreign expansion: South Korean firms and business groups in China, 1987-1995. Academy of Management Journal, 45(3), 509-525.

Gupta, S., Davoodi, H., \& Alonso-Terme, R. (2002). Does corruption affect income inequality and poverty? Economics of Governance, 3(1), 23-45.

Gutmann, J. (2015). Believe, but verify?: The effect of market structure on corruption in religious organizations. Kyklos, 68(2), $153-164$.

Gutmann, J., \& Lucas, V. (2018). Private-sector corruption: Measurement and cultural origins. Social Indicators Research, 138(2), $747-770$.

Habib, M., \& Zurawicki, L. (2002). Corruption and foreign direct investment. Journal of International Business Studies, 33(2), 291-308.

Handa, I. (2016). Fallacies in the current methods of prosecuting international commercial bribery. Cardozo Law Review, 38(2), $725-760$.

Hansen, H. K. (2011). Managing corruption risks. Review of International Political Economy, 18(2), 251-275.

Hauser, C. (2018). Fighting against corruption: Does anti-corruption training make any difference? Journal of Business Ethics. https ://doi.org/10.1007/s10551-018-3808-3.

Heeks, R., \& Mathisen, H. (2012). Understanding success and failure of anti-corruption initiatives. Crime, Law and Social Change, $58(5), 533-549$.

Henisz, W. J. (2002). The institutional environment for infrastructure investment. Industrial and Corporate Change, 11(2): 355-389.

Hess, D. (2009). Corruption in the value chain: Private-to-private and private-to-public corruption. In D. Zinnbauer, R. Dobson \& K. Despota (Eds.), Global corruption report: Corruption and the private sector (pp. 19-23). New York: Cambridge University Press.

Hodgson, G. M., \& Jiang, S. (2007). The economics of corruption and the corruption of economics: An institutionalist perspective. Journal of Economic Issues, 41(4), 1043-1061.

Hoffmann, D. A., Griffin, M. A., \& Gavin, M. B. (2000). The application of hierarchical linear modeling to organizational research. In K. J. Klein \& S. W. J. Kozlowski (Eds.), Multilevel theory, research and methods in organizations (pp. 467-511). San Francisco: Jossey-Bass. 
Holtmeier, J. (2015). Cross-border corruption enforcement: A case for measured coordination among multiple enforcement authorities. Fordham Law Review, 84(2), 493-524.

Husted, B. W. (1994). Honor among thieves: A transaction-cost interpretation of corruption in third world countries. Business Ethics Quarterly, 4(1), 17-27.

International Monetary Fund. (2016). Corruption: Costs and mitigating strategies. Washington, DC: International Monetary Fund.

Javorcik, B. S., \& Wei, S.-J. (2009). Corruption and cross-border investment in emerging markets: Firm-level evidence. Journal of International Money and Finance, 28(4), 605-624.

Jiménez, A., Benito-Osorio, D., Puck, J., \& Klopf, P. (2018). The multi-faceted role of experience dealing with policy risk: The impact of intensity and diversity of experiences. International Business Review, 27(1), 102-112.

Johnsen, D. B. (2009). The ethics of "commercial bribery": Integrative social contract theory meets transaction cost economics. Journal of Business Ethics, 88, 791-803.

Jordan, J. (2016). World tours and the Summer Olympics: Recent pitfalls under the Foreign Corrupt Practices Act in the areas of gifts, entertainment and travel. Fordham Journal of Corporate and Financial Law, 21(2), 295-326.

Jung, J. C., \& Lee, K.-P. (2017). Host country sourcing of multinational enterprises: A corporate social responsibility perspective. Journal of Business Ethics, 152(3), 683-701.

Karjalainen, K., \& Moxham, C. (2013). Focus on Fairtrade: Propositions for integrating Fairtrade and supply chain management research. Journal of Business Ethics, 116(2), 267-282.

Kim, S. H. (2014). Insider trading as private corruption. UCLA Law Review, 61, 928-1008.

Krishnan, R., Martin, X., \& Noorderhaven, N. G. (2006). When does trust matter to alliance performance? Academy of Management Journal, 49(5), 894-917.

Lambsdorff, J., Taube, M., \& Schramm, M. (2005). Corrupt contracting: Exploring the analytical capacity of new institutional economics and new economic sociology. In J. Lambsdorff, M. Taube \& M. Schramm (Eds.), The new institutional economics of corruption (pp. 1-15). New York: Routledge.

Lambsdorff, J. G. (2002a). How confidence facilitates illegal transactions. American Journal of Economics and Sociology, 61(4), 829-853.

Lambsdorff, J. G. (2002b). Making corrupt deals: Contracting in the shadow of the law. Journal of Economic Behavior \& Organization, 48(3), 221-241.

Lambsdorff, J. G. (2007). Making corrupt deals: Contracting in the shadow of the law. In J. G. Lambsdorff (Ed.), The institutional economics of corruption and reform: Theory, evidence and policy (pp. 136-163). Cambridge: Cambridge University Press.

Lambsdorff, J. G., \& Schulze, G. G. (2015). What can we know about corruption?: A very short history of corruption research and a list of what we should aim for. Journal of Economics and Statistics (Jahrbuecher fuer Nationaloekonomie und Statistik), 235(2), 100-114

Lange, D. (2008). A multidimensional conceptualization of organizational corruption control. Academy of Management Review, 33(3), 710-729.

Li, N. (2008). Religion, opportunism and international market entry via non-equity alliances or joint ventures. Journal of Business Ethics, 80(4), 771-789.

Li, R. (2013). Media corruption: A Chinese characteristic. Journal of Business Ethics, 116(2), 297-310.

Lindgreen, A. (2004). Corruption and unethical behavior: Report on a set of Danish guidelines. Journal of Business Ethics, 51(1), 31-39.
Liu, X. (2015). Applied ordinal logistic regression using Stata: From single-level to multilevel modeling. Los Angeles: Sage Publications.

Long, J. S., \& Freese, J. (2014). Regression models for categorical dependent variables using Stata (3rd ed.). College Station: Stata Press.

Luiz, J. M., \& Stewart, C. (2014). Corruption, South African multinational enterprises and institutions in Africa. Journal of Business Ethics, 124(3), 383-398.

Luke, D. A. (2004). Multilevel modeling. Thousand Oaks: Sage Publications.

Luo, Y. (2004). Building a strong foothold in an emerging market: A link between resource commitment and environment conditions. Journal of Management Studies, 41(5), 749-773.

Luo, Y. (2005). An organizational perspective of corruption. Management and Organization Review, 1(1), 119-154.

Luo, Y. (2007). An integrated anti-opportunism system in international exchange. Journal of International Business Studies, $38(6), 855-877$.

Luo, Y. D. (2001). Determinants of entry in an emerging economy: A multilevel approach. Journal of Management Studies, 38(3), 443-472.

Madhok, A. (1996). The organization of economic activity: Transaction costs, firm capabilities, and the nature of governance. Organization Science, 7(5), 577-590.

Madhok, A. (1997). Cost, value and foreign market entry mode: The transaction and the firm. Strategic Management Journal, 18(1), 39-61.

Mercier, G., \& Deslandes, G. (2017). There are no codes, only interpretations. Practical wisdom and hermeneutics in monastic organizations. Journal of Business Ethics, 145(4), 781-794.

Meschi, P. X. (2009). Government corruption and foreign stakes in international joint ventures in emerging economies. Asia Pacific Journal of Management, 26(2), 241-261.

Meyer, K. E. (2004). Perspectives on multinational enterprises in emerging economies. Journal of International Business Studies, 35(4), 259-276.

Meyer, K. E., \& Nguyen, H. V. (2005). Foreign investment strategies and sub-national institutions in emerging markets: Evidence from Vietnam. Journal of Management Studies, 42(1), 63-93.

Meyer, K. E., Wright, M., \& Pruthi, S. (2009). Managing knowledge in foreign entry strategies: A resource-based analysis. Strategic Management Journal, 30(5), 557-574.

Miller, K. D. (1992). A framework for integrated risk management in international business. Journal of International Business Studies, 23(2), 311-331.

Milliken, F. J. (1987). Three types of perceived uncertainty about the environment: State, effect, and response uncertainty. Academy of Management Review, 12(1), 133-143.

Milliken, F. J. (1990). Perceiving and interpreting environmental change: An examination of college administrators' interpretation of changing demographics. Academy of Management Journal, 33(1), 42-63.

Montiel, I., Christmann, P., \& Zink, T. (2016). The effect of sustainability standard uncertainty on certification decisions of firms in emerging economies. Journal of Business Ethics. https://doi. org/10.1007/s10551-016-3350-0.

Montiel, I., Husted, B. W., \& Christmann, P. (2012). Using private management standard certification to reduce information asymmetries in corrupt environments. Strategic Management Journal, 33(9), 1103-1113.

Narayanan, M., Schipani, C., \& Seyhun, H. (2007). The economic impact of backdating of executive stock options. Michigan Law Review, 105(8), 1597-1641. 
Noorderhaven, N. G. (1996). Opportunism and trust in transaction cost economics. In J. Groenewegen (Ed.), Transaction cost economics and beyond (pp. 105-128). Boston: Springer.

Nooteboom, B., Berger, H., \& Noorderhaven, N. G. (1997). Effects of trust and governance on relational risk. Academy of Management Journal, 40(2), 308-338.

North, D. C. (1990). Institutions, institutional change and economic performance. New York: Cambridge University Press.

Nunnally, J., \& Bernstein, I. (1994). Psychometric theory. New York: McGraw-Hill.

Orudzheva, L., Salimath, M. S., \& Pavur, R. (2018). Vortex of corruption: Longitudinal analysis of normative pressures in top global companies. Journal of Business Ethics. https://doi. org/10.1007/s10551-018-4022-z.

Painter-Morland, M. (2010). Questioning corporate codes of ethics. Business Ethics: A European Review, 19(3), 265-279.

Park, S., \& Ungson, G. (1997). The effect of national culture, organizational complementarity, and economic motivation on joint venture dissolution. Academy of Management Journal, 40(2), 279-307.

Persson, A., Rothstein, B., \& Teorell, J. (2013). Why anticorruption reforms fail: Systemic corruption as a collective action problem. Governance, 26(3), 449-471.

Peterson, M. F., Arregle, J. L., \& Martin, X. (2012). Multilevel models in international business research. Journal of International Business Studies, 43(5), 451-457.

Petrou, A. P. (2015). Arbitrariness of corruption and foreign affiliate performance: A resource dependence perspective. Journal of World Business, 50(4), 826-837.

Pfarrer, M. D., Decelles, K. A., Smith, K. G., \& Taylor, M. S. (2008). After the fall: Reintegrating the corrupt organization. Academy of Management Review, 33(3), 730-749.

Powell, K. S., \& Rhee, M. (2016). Experience in different institutional environments and foreign subsidiary ownership structure. Journal of Management, 42(6), 1434-1461.

Rabe-Hesketh, S., \& Skrondal, A. (2008). Multilevel and longitudinal modeling using Stata (2nd ed.). College Station: Stata Press.

Ralston, D. A., Egri, C. P., Reynaud, E., Srinivasan, N., Furrer, O., Brock, D., Alas, R., Wangenheim, F., Darder, F. L., \& Kuo, C. (2011). A twenty-first century assessment of values across the global workforce. Journal of Business Ethics, 104(1), 1-31.

Remišová, A., Lašáková, A., \& Kirchmayer, Z. (2018). Influence of formal ethics program components on managerial ethical behavior. Journal of Business Ethics. https://doi.org/10.1007/s1055 1-018-3832-3.

Reuer, J. J., \& Ragozzino, R. (2014). Signals and international alliance formation: The roles of affiliations and international activities. Journal of International Business Studies, 45(3), 321-337.

Robertson, C. J., Lamin, A., \& Livanis, G. (2010). Stakeholder perceptions of offshoring and outsourcing: The role of embedded issues. Journal of Business Ethics, 95(2), 167-189.

Rodriguez, P., Siegel, D. S., Hillman, A. J., \& Eden, L. (2006). Three lenses on the multinational enterprise: Politics, corruption, and corporate social responsibility. Journal of International Business Studies, 37(6), 733-746.

Rodriguez, P., Uhlenbruck, K., \& Eden, L. (2005). Government corruption and the entry strategies of multinationals. Academy of Management Review, 30(2), 383-396.

Romar, E. J. (2004). Globalization, ethics and opportunism: A Confucian view of business relationships. Business Ethics Quarterly, 14(4), 663-678.

Rose-Ackerman, S. (1997). The role of the World Bank in controlling corruption. Law \& Policy in International Business, 29, 93-114.

Rose-Ackerman, S. (2007). Measuring private sector corruption. U4 Brief. (Chr. Michelsen Institute), 2007(5), 1-5.
Rose-Ackerman, S. (2010). The law and economics of bribery and extortion. Annual Review of Law and Social Science, 6, 217-238.

Rose-Ackerman, S., \& Palifka, B. J. (2016). Corruption and government: Causes, consequences and reform (2nd ed.). New York: Cambridge University Press.

Rothstein, B. (2005). Social traps and the problem of trust. New York: Cambridge University Press.

Rousso, A., \& Steves, F. (2006). The effectiveness of anti-corruption programs: Preliminary evidence from the post-communist transition countries. In S. Rose-Ackerman (Ed.), International handbook on the economics of corruption (pp. 247-277). Northampton: Edward Elgar Publishing, Inc.

Roy, J. P. (2012). IJV partner trustworthy behaviour: The role of host country governance and partner selection criteria. Journal of Management Studies, 49(2), 332-355.

Roy, J. P., \& Oliver, C. (2009). International joint venture partner selection: The role of the host-country legal environment. Journal of International Business Studies, 40(5), 779-801.

Rugman, A. M., \& Verbeke, A. (2003). Extending the theory of the multinational enterprise: Internalization and strategic management perspectives. Journal of International Business Studies, 34(2), 125-137.

Sampath, V. S., Gardberg, N. A., \& Rahman, N. (2018). Corporate reputation's invisible hand: Bribery, rational choice and market penalties. Journal of Business Ethics, 151(3), 743-760.

Sartor, M. A., \& Beamish, P. W. (2014). Offshoring innovation to emerging markets: Organizational control and informal institutional distance. Journal of International Business Studies, 45(9), 1072-1095.

Sartor, M. A., \& Beamish, P. W. (2018). Host market government corruption and the equity-based foreign entry strategies of multinational enterprises. Journal of International Business Studies, 49(3), 346-370.

Schoeneberger, J. A. (2016). The impact of sample size and other factors when estimating multilevel logistic models. Journal of Experimental Education, 84(2), 373-397.

Schwens, C., Eiche, J., \& Kabst, R. (2011). The moderating impact of informal institutional distance and formal institutional risk on SME entry mode choice. Journal of Management Studies, 48(2), 330-351.

Shi, W., Connelly, B. L., \& Sanders, W. (2015). Buying bad behavior: Tournament incentives and securities class action lawsuits. Strategic Management Journal, 37(7), 1354-1378.

Shleifer, A., \& Vishny, R. W. (1993). Corruption. Quarterly Journal of Economics, 108(3), 599-617.

Siegel, D. S. (2014). Responsible leadership. Academy of Management Perspectives, 28(3), 221-223.

Smith, J. (2018). Efficiency and ethically responsible management. Journal of Business Ethics, 150(3), 603-618.

Smith, W. K., \& Lewis, M. W. (2011). Toward a theory of paradox: A dynamic equilibrium model of organizing. Academy of Management Review, 36(2), 381-403.

Søreide, T. (2006). Corruption in international business transactions: The perspective of Norwegian firms. In S. Rose-Ackerman (Ed.), International handbook on the economics of corruption (pp. 381-417). Northampton: Edward Elgar Publishing.

Spence, E. H. (2017). Corruption in the media. In M. S. Aßländer \& S. Hudson (Eds.), The handbook of business and corruption: Cross-sectoral experiences (pp. 453-480). Bingley: Emerald Publishing.

Tabachnick, B., \& Fidell, L. (2007). Using multivariate statistics (5th ed.). Boston: Allyn \& Bacon.

The Economist. (2010, May 1). The corruption eruption. The Economist, p. 73.

The Economist. (2017, November, 25). Defrauding the do-gooders. The Economist, pp. 55-56. 
Toyo Keizai Inc. Kaigai Shinshutsu Kigyou Souran. Tokyo, Japan: Toyo Keizai Inc.

Transparency International. (2016). Corruption Perceptions Index 2015. Berlin: Transparency International.

Trapnell, S., Jenkins, M., \& Chene, M. (2017). Monitoring corruption and anti-corruption in the Sustainable Development Goals. Berlin: Transparency International.

Tridico, P. (2012). Financial crisis and global imbalances: Its labour market origins and the aftermath. Cambridge Journal of Economics, 36(1), 17-42.

Trivunovic, M., Johnsøn, J., \& Mathisen, H. (2011). Developing an NGO corruption risk management system: Considerations for donors (Vol. 9, pp. 1-26). U4 Issue. Bergen: Chr. Michelsen Institute.

Uhlenbruck, K., Rodriguez, P., Doh, J. P., \& Eden, L. (2006). The impact of corruption on entry strategy: Evidence from telecommunication projects in emerging economies. Organization Science, 17(3), 402-414.

UNCTAD. (2017). World investment report 2017: Investment and the digital economy. Geneva: United Nations Conference on Trade and Development.

United Nations. (2015). Transforming our world: The 2030 agenda for sustainable development. New York: United Nations.

Vadera, A. K., Aguilera, R. V., \& Caza, B. B. (2009). Making sense of whistle-blowing's antecedents: Learning from research on identity and ethics programs. Business Ethics Quarterly, 19(4), 553-586.

Van Vu, H., Tran, T. Q., Van Nguyen, T., \& Lim, S. (2018). Corruption, types of corruption and firm financial performance: New evidence from a transitional economy. Journal of Business Ethics, 148(4), 847-858.

Verbeke, A. (2003). The evolutionary view of the MNE and the future of internalization theory. Journal of International Business Studies, 34(6), 498-504.

Verbeke, A., \& Asmussen, C. G. (2016). Global, local, or regional? The locus of MNE strategies. Journal of Management Studies, 53(6), 1051-1075.

Voegtlin, C., \& Scherer, A. G. (2017). Responsible innovation and the innovation of responsibility: Governing sustainable development in a globalized world. Journal of Business Ethics, 143(2), 227-243.

Voyer, P., \& Beamish, P. (2004). The effect of corruption on Japanese foreign direct investment. Journal of Business Ethics, 50(3), 211-224.

Wan, W. P. (2005). Country resource environments, firm capabilities and corporate diversification strategies. Journal of Management Studies, 42(1), 161-182.

Weismann, M. F. (2009). The Foreign Corrupt Practices Act: The failure of the self-regulatory model of corporate governance in the global business environment. Journal of Business Ethics, 88(4), 615-661.

Weismann, M. F., Buscaglia, C. A., \& Peterson, J. (2014). The Foreign Corrupt Practices Act: Why it fails to deter bribery as a global market entry strategy. Journal of Business Ethics, 123(4), 591-619.

Williamson, O. E. (1985). The economic institutions of capitalism. New York: The Free Press.

Xie, X., Qi, G., \& Zhu, K. X. (2018). Corruption and new product innovation: Examining firms' ethical dilemmas in transition economies. Journal of Business Ethics. https://doi.org/10.1007/ s10551-018-3804-7.

Xu, D., \& Meyer, K. E. (2013). Linking theory and context: 'Strategy research in emerging economies' after Wright et al. (2005). Journal of Management Studies, 50(7), 1322-1346.

Yiu, D., \& Makino, S. (2002). The choice between joint venture and wholly owned subsidiary: An institutional perspective. Organization Science, 13(6), 667-683.

Zinnbauer, D., Dobson, R., \& Despota, K. (Eds.). (2009). Global corruption report: Corruption and the private sector. New York: Cambridge University Press.

Publisher's Note Springer Nature remains neutral with regard to jurisdictional claims in published maps and institutional affiliations. 